\title{
The Impact of Oil Price on Transition toward Renewable Energy Consumption? Evidence from Russia
}

\author{
Rıdvan Karacan ${ }^{1, *}$, Shahriyar Mukhtarov $2,3, * \mathbb{C}$, İsmail Barış ${ }^{4}$, Aykut İşleyen ${ }^{5}$ and Mehmet Emin Yardımcı ${ }^{6}$ \\ 1 Department of Economy, Kocaeli University, Kocaeli 41800, Turkey \\ 2 Department of Economics, Baku Engineering University, Hasan Aliyev 120, \\ Khirdalan, Baku AZ0101, Azerbaijan \\ 3 Faculty of Economics and International Relations, Vistula University, Stoklosy 3, 02-787 Warsaw, Poland \\ 4 Department of Social Work, Uskudar University, İstanbul 34662, Turkey; ismail.baris@uskudar.edu.tr \\ 5 Department of Business Administration, Hitit University, Çorum 19030, Turkey; aykutisleyen@hitit.edu.tr \\ 6 Faculty of Economics and Administrative Sciences, Kocaeli University, Kocaeli 41040, Turkey; \\ emin.yardimci@kocaeli.edu.tr \\ * Correspondence: rkaracan@kocaeli.edu.tr (R.K.); smuxtarov@beu.edu.az or s.mukhtarov@vistula.edu.pl (S.M.)
}

Citation: Karacan, R.; Mukhtarov, S.; Barış, İ.; İşleyen, A.; Yardımcı, M.E. The Impact of Oil Price on Transition toward Renewable Energy Consumption? Evidence from Russia. Energies 2021, 14, 2947. https:// doi.org/10.3390/en14102947

Academic Editor:

Magdalena Radulescu

Received: 12 April 2021

Accepted: 15 May 2021

Published: 19 May 2021

Publisher's Note: MDPI stays neutral with regard to jurisdictional claims in published maps and institutional affiliations.

Copyright: (C) 2021 by the authors Licensee MDPI, Basel, Switzerland. This article is an open access article distributed under the terms and conditions of the Creative Commons Attribution (CC BY) license (https:// creativecommons.org/licenses/by/ $4.0 /)$.

\begin{abstract}
This research investigates the impact of oil price, income and carbon dioxide emissions on renewable energy consumption in Russia for the data period from 1990 to 2015, using the Vector Error Correction Models and the Canonical Cointegrating Regression method. This article is the only study conducting individual time-series analysis that emphasizes the effect of oil price on renewable energy consumption in the case of Russia. The results of empirical analysis conclude that oil price affects renewable energy consumption negatively. The negative oil price effects on renewable energy use can be interpreted as a sign of issue that stems from higher oil prices and slows the transition from conventional to renewable energy sources. Additionally, we found that there is a positive and statistically significant influence of real GDP per capita as a proxy of income on renewable energy consumption, whereas the carbon dioxide emissions have a negative and statistically insignificant influence on renewable energy consumption. Considering these empirical results, Russia, which has a significant share in energy production in the world, should focus on the use of renewable energy in order to maintain this superiority and its sustainability. The findings of this paper may be useful to policymakers and may help to contribute to existing literature for future research in the case of oil-exporting countries.
\end{abstract}

Keywords: income; renewable energy; oil price; VECM; CCR; Russia

\section{Introduction}

All activities in nature take place by the courtesy of energy. Therefore, energy is an indispensable element of natural life. Unlike other beings, humans have succeeded in transforming fossil fuels into energy by using their intelligence and the opportunities offered by nature. In this way, the production has been based on fossil fuels for about two centuries. However, fossil fuels pollute the air because they contain high levels of carbon [1-4]. It is a known fact that the use of fossil fuels (coal, oil, and natural gas) causes global warming. Global warming causes more severe weather conditions, droughts, forest fires, rising sea levels, and floods, among other effects [5].

The use of some fossil fuels, such as natural gas, coal, and oil, currently meets most of the world's growing energy demand but is destined to run out relatively quickly. In this context, the necessity of alternative energy systems is of great importance in terms of sustainability [6,7]. Renewable energy plays a vital role in the sustainable development of a society today [8]. If we are to plan our future considering known energy sources, the only option is sustainable renewable energy sources. In this context, it will be of great benefit if renewable energies such as solar, wind, biomass, and water can be used in all sectors (industry, housing, and transportation) [9]. 
Renewable energy is defined as energy obtained from inexhaustible sources that generate low levels of greenhouse gas emissions [10]. The policy of increasing the share of renewable energy in countries around the world is high on the agenda. Several governments have set ambitious goals and have started establishing support programs aiming to facilitate the implementation of a market. The degree of success of these policies may differ among countries [11]. This difference may arise due to their relative position as an oil importer or exporter and their tax structure [12]. Another difference between oil importing and exporting countries is due to fluctuations in oil prices. An increase in oil prices may occur due to political events [13], global demand shocks [14], the appreciation of the US dollar [15], contraction in production [16], and an increase in costs [17]. In this context, while increasing oil prices will encourage more oil production in the exporting country, it will adversely affect renewable energy investments. In case of a decrease in oil prices, a similar process will be experienced for the importing country.

It is also possible to see the positive effect of high crude oil prices on the renewable energy sector through the improvement in the stock market performance of energy companies [18]. Studies [19-21] suggest that there is a positive relationship between the stock prices of renewable energy companies, and crude oil prices confirm this situation. The roots of this positive bond are that clean energy is often seen as a substitute for fossil fuel energy [18]. In this context, public spending aimed at gradually reducing dependence on fossil fuels and carbon dioxide emissions can be reduced when it provides the necessary incentives for those who want to invest in the renewable energy industry [22]. In addition, the use of renewable energy sources can be a strategy to reduce environmental degradation and import dependency, in particular. This will contribute to preventing the unwanted consequences of fluctuating oil prices in energy-dependent countries [23].

Renewable energy is commonly considered as an alternative for crude oil in both consumption and output of other energy sources, according to the literature. From this perspective, a positive link between oil prices and renewable energy demand is anticipated, because increasing oil prices would give incentives to firms and households to decrease their consumption, buy more energy-efficient goods, and switch from traditional to renewable energy [24]. In point of fact, high oil prices should encourage more investment in renewable energy sources. High oil prices by 2015 necessitated a less expensive alternative, although low oil prices were anticipated to decrease investment in alternative energy sources. Before the recent steep drop in oil prices, this theory was right. It is claimed that oil price instability is one of the causes for green energy's rising appeal as a means of declining oil dependency, making it vulnerable to price shocks. Although, declining oil dependency has become a major issue not only for oil-importing countries, but also for oil-exporting countries, especially after oil prices fell sharply between 2008 and 2014 [25]. When oil prices are higher, oil-exporting countries can take advantage of ample resources available to provide subsidies to domestic users, resulting in a rise in conventional energy consumption and a lack of motivation for producers and consumers to rely on alternative energy sources. During periods of high oil prices, though, it could be appropriate to invest oil revenues in renewable energy ventures and boost renewable energy use. In addition, oil-exporting countries should export oil products and encourage renewable energy use domestically, thus rising renewable energy use. On the other hand, higher oil prices deter the use of oil products and encourage the reliance on renewable sources, which could lead to a rise in renewable energy demand in oil-importing countries [26]. In the literature, it is possible to see some studies examining the impact of oil prices on renewable energy consumption in the case of both oil-exporting and oil-importing countries. These studies have approved the above-mentioned facts. For example, Sadorsky [27] for G7 countries, Salim and Rafiq [28] for China and Indonesia, Omri and Nguyen [29] for 64 countries, Deniz [25] for oil-exporting countries and Mukhtarov et al. [26] for Azerbaijan, and Murshed and Tanha [30] for Bangladesh, India, Pakistan, and Sri Lanka, concluded a negative effect of oil price on renewable energy consumption. Moreover, Marques and Fuinhas [31] in the case of 24 European Union countries, Salim and Rafiq [28] in the case of Brazil, India, 
Philippines, and Turkey, and Nguyen and Kakinaka [32] in the case of middle-income countries, found an insignificant effect of oil price on renewable energy consumption. As a result, country-specific studies are necessary to determine how renewable energy demand responds to oil prices. In light of the above, it is crucial to investigate how oil price fluctuation influences economies' efforts to shift from conventional to renewable energy consumption.

The influence of oil price on renewable energy use varies from country to country. Therefore, studies conducted in the country can make different contributions to the literature. As a result of the investigations, it was found that there was no such study in Russia, using country-specific time-series data. Therefore, the key goal of this article is to conduct a study for Russia, by investigating the impact of oil price on renewable energy consumption, utilizing Vector Error Correction Models (VECM) and Canonical Cointegrating Regression (CCR) techniques. The contributions of this paper are as follows: (a) it examined the relationship between renewable energy use and GDP per capita in Russia, which has not been studied before in an energy-income context and is a good example for similar oil-exporting countries, and (b) to the best of our investigation, this article is the first time-series analysis of the effect of oil prices on renewable energy consumption for Russia.

The structure of the paper is as follows: The background of renewable energy in Russia is described in Section 2. Section 3 provides a summary of the current literature. Section 4 contains a summary of the data as well as the methodology. Section 5 contains a discussion of the study's findings. The conclusion and policy implications are given in Section 6.

\section{Energy and Renewable Energy in Russia}

Russia has great potential in terms of energy production dependent on fossil fuels. However, fossil fuel resources, which are already limited during this period when the population and needs are growing rapidly, are declining every day. In addition, the damage caused by fossil fuels to the environment and human health has begun to be better understood. Realizing this situation, the global energy industry has entered a new structuring process in terms of obtaining energy and has turned to renewable energy sources as an alternative. However, Russia has not yet made satisfactory progress on this issue. What is the reason for Russia's slow progress, while many developed countries have made significant progress? The study was conducted to find the answer to this question, because Russia needs renewable energy policies in which it can compete on equal runs in the future in terms of the sustainability of its current energy superiority. In order to test the need for a sustainable energy policy, it is necessary to first examine the country's energy production and consumption.

As well as being the biggest global crude oil producer, Russia holds the second place in dry natural gas production too. In addition, Russia produces large quantities of coal. Russia's economy is highly reliant on hydrocarbons, with oil and gas revenues accounting for more than 33\% of federal budget revenues [33]. The Figure 1 below shows the world ranking of Russia in terms of energy production.

Total consumption per capita in Russia reached 5.3 TEP in 2019. The average annual electricity consumption per person is about $6400 \mathrm{kWh}$. Total energy consumption increased by $2.6 \%$ year-on-year since 2015 , to 768 in 2019 . Previously, there was a slight decline between 2012 and 2015 (-1\%/year) due to the economic slowdown and the recession in 2015. In 2019, Gas had the largest portion of consumption (54\%), while the consumption of other fossil fuels such as oil (20\%), coal (16\%), nuclear (7\%), hydro (2\%), and biomass (1\%) were lower [34]. The Figure 2 below depicts the annual changes in Russia's primary energy consumption as a percentage of the previous year. 


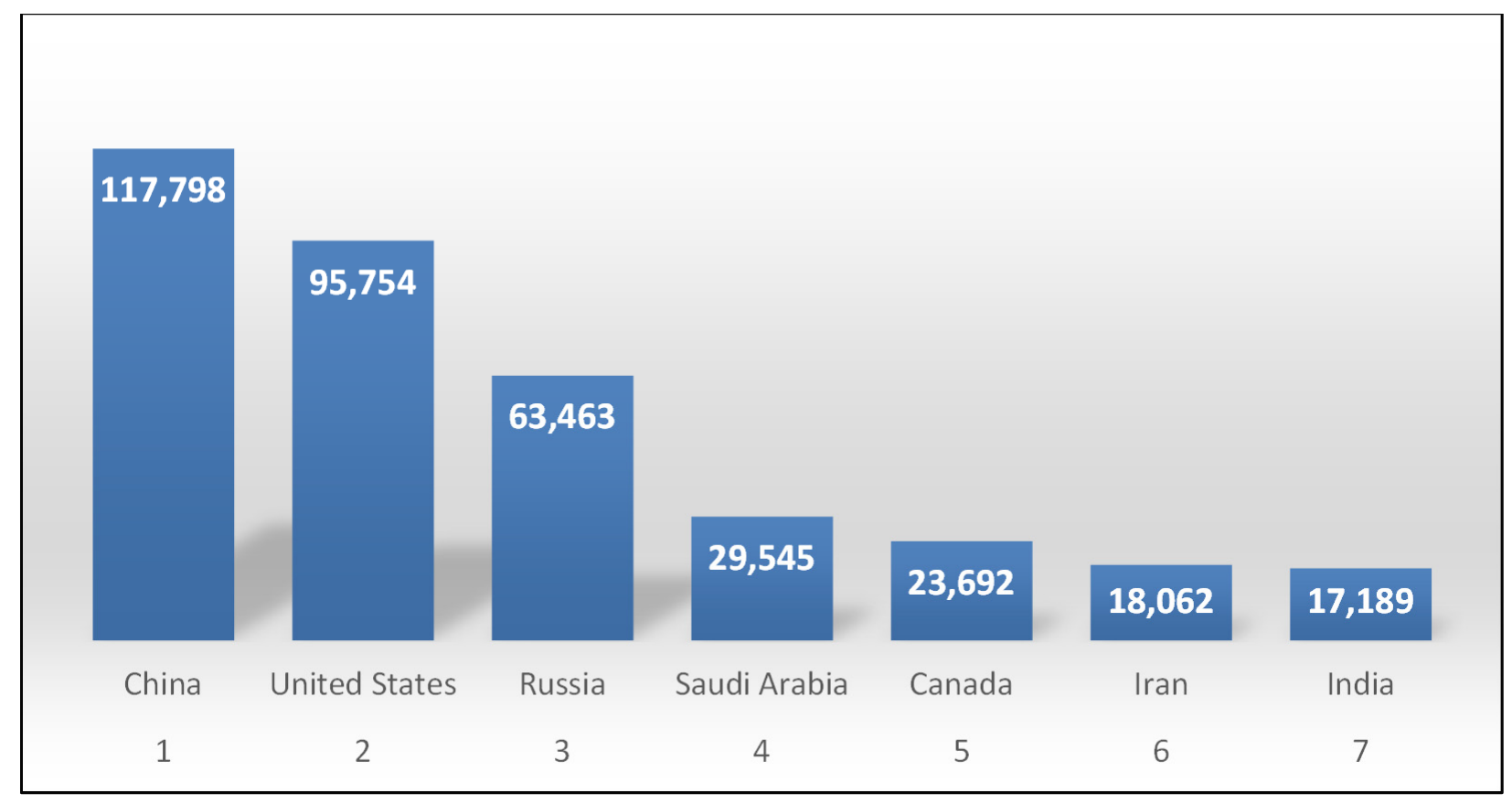

Figure 1. Total energy production. Source: [33].

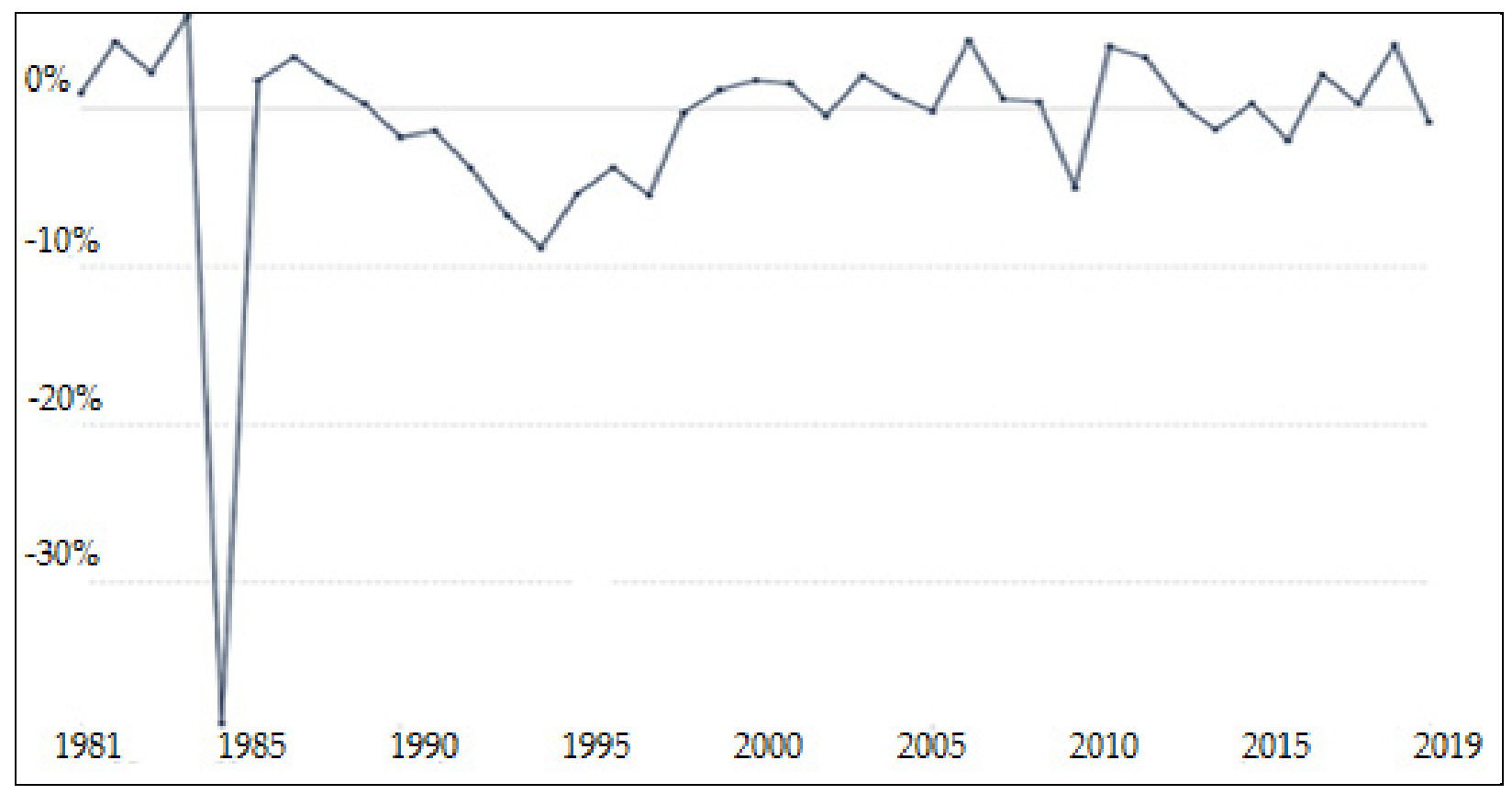

Figure 2. Annual change in Russia's primary energy consumption. Source: [35].

In the chart, the most important reason why Russia's energy consumption continued during the same period is the slow growth in the economy.

It is necessary to emphasize that most regions of Russia are insufficient in terms of energy, they need fuel and energy supplies. The solution to this regional energy problem is just like countries importing energy resources. Although there are rich natural gas reserves, about $50 \%$ of cities and about $35 \%$ of rural communities can use natural gas. Coal and petroleum products are mainly used in areas that lack natural gas. This causes environmental pollution [36]. Since carbon dioxide $\left(\mathrm{CO}_{2}\right)$ emissions are inversely proportional to energy consumption, $\mathrm{CO}_{2}$ emissions from fossil fuels are mainly used as a proxy for energy efficiency. Russia's greenhouse gas emissions have declined by 21.5 percent 
to 1467.6 million tons of $\mathrm{CO}_{2}$ since 1991. The main reason for this is the decline in coal consumption and the increase in gas consumption [37].

In recent years, Russia's energy sector has undergone many reforms. All of these reforms help Russia have more liberalized electricity and natural gas markets and determine the prices closer to global market levels. Despite this, it falls behind other emerging countries with regard to efficient use of its energy [38].

As a traditional fossil fuel user, Russia is turning to alternative energy sources in order to improve the energy efficiency of its economy. Russia has the ability to expand the utilization of renewable energy by using its vast resources of various forms, covering bioenergy, geothermal, hydro, solar, and wind [39]. This capacity is fairly uniformly distributed across the country's 17.1 million $\mathrm{km}^{2}$ surface area. The Caucasus Mountains, on the Mongolian border, and near Vladivostok are the most promising areas for solar energy production. The average annual daily amount of solar radiation falling on the surface at an angle equal to the latitude ranges in these areas ranges from 4 to $5.5 \mathrm{kwh} / \mathrm{m}^{2}$ per day [40]. Although Russia is one of the first countries to lead the improvement of alternative energy technologies worldwide, unfortunately, it has not been able to make the expected progress over time, instead taking the preferred the path of improving fossil fuels and nuclear energy [41]. It is possible to see this situation more clearly in the Figure 3 below.

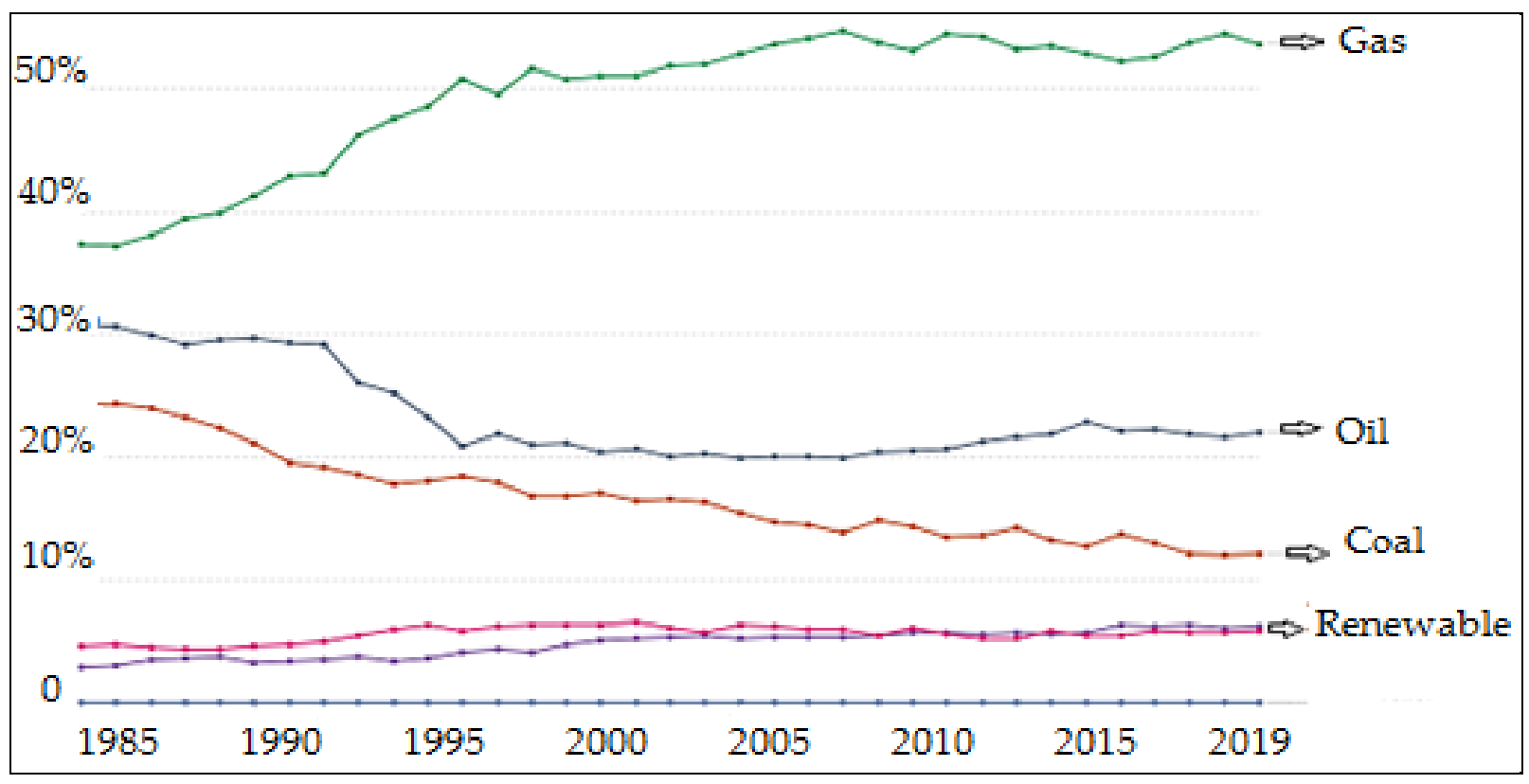

Figure 3. Share of energy consumption by source (quad Btu). Source: [35].

By 2035, renewable energy should account for 4.9 percent of Russia's overall primary energy consumption, up from 3.2 percent today. This covers Russia's plan to increase total solar photoelectric (PV), onshore wind, and geothermal capacity to 5.9 GW by 2024, which has been approved. Decree No. 449, which was passed in 2013 and provides a legal structure for the country's renewable energy capacity scheme, is the foundation for the development of renewable energy in Russia. The decree aims to promote the production of renewable energy, with a particular emphasis on wind and solar PV, as well as smallscale hydropower to a lesser degree. The law lays out the terms in which the country will participate in renewable energy markets [42]. Russia's energy policy emphasizes the stature of local production improvement, in the renewable energy sector. The state encourages potential investors to run production of high-tech components for powergenerating facilities in Russia to improve competitive local technologies and production in the country [43]. The Figure 4 below shows the energy renewable technology mix in Russia. 


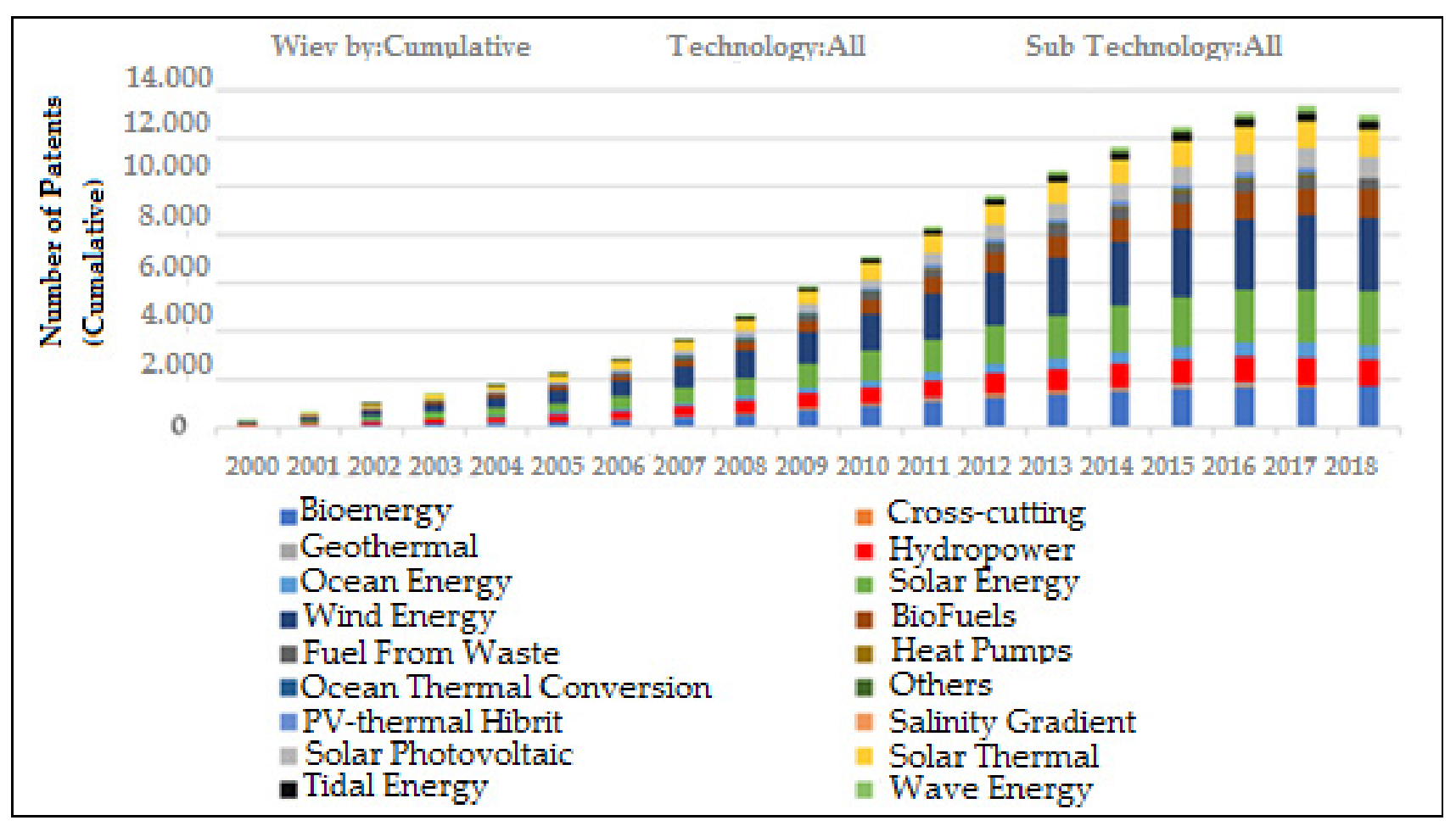

Figure 4. The energy technology mix in Russia. Source: [44].

Russia has the capacity to increase the use of all types of clean energy technology. The creation of a larger renewable energy sector in Russia would offer benefits for multiple sectors of the Russian economy, stimulating activity and job growth in the country [39].

\section{Literature Review}

The impacts of oil price on renewable energy consumption (REC) have been extensively examined, and varying results for different countries were obtained. Empirically, it is argued by many studies, such as Sadorsky [27] for G7 countries, Salim and Rafiq [28] for China and Indonesia, Omri and Nguyen [29] for 64 countries, Deniz [25] for oil-exporting countries, Mukhtarov et al. [26] for Azerbaijan, and Murshed and Tanha [30] for Bangladesh, India, Pakistan, and Sri Lanka, who revealed that oil price has adverse impact on REC. However, a positive effect from oil price to REC was reached by Omri and Nguyen [25], Apergis and Payne [45], Apergis and Payne [46], Azad et al. [47], Apergis and Payne [48], and Bamati and Roofi [49]. On the other hand, some recent empirical investigations, such as Marques and Fuinhas [31] in the case of 24 European Union countries, Tuzcu and Tuzcu [50] in the case of 7 OPEC members, and Nguyen and Kakinaka [32] in the case of for middle-income countries, found statistically insignificant effects of oil prices on REC. In addition, Brini et al. [51] found an absence of cointegration relationship between oil price in Tunisia and REC, while Alege [52] found the existence of a cointegration link between used variables in 40 Sub-Saharan African countries. Table 1 summarizes the related literature. 
Table 1. An overview of the empirical research.

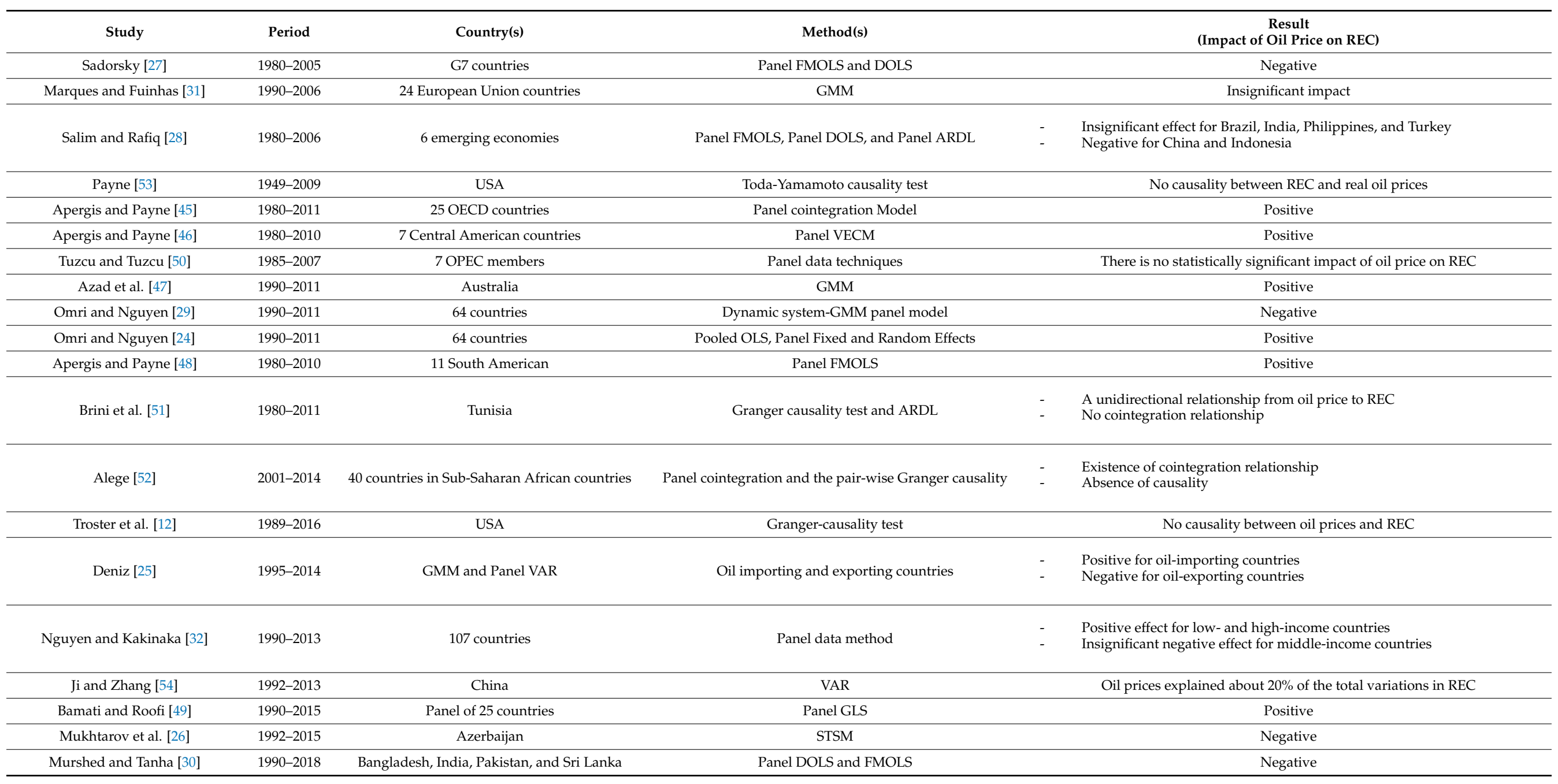




\section{Model and Data}

\subsection{Functional Specification and Data}

Based on Mukhtarov et al. [26], the functional specification in this paper can be expressed as below:

$$
\ln R E C_{t}=\beta_{0}+\beta_{1} \ln O P_{t}+\beta_{2} \ln G D P_{t}+\beta_{3} \ln C O_{2, t}+\varepsilon_{t}
$$

where, $R E C_{t}$ is renewable energy consumption, $O P_{t}$ is oil price, $G D P_{t}$ is income proxied by real GDP per capita, $\mathrm{CO}_{2, t}$ is carbon dioxide emissions per capita, and $\varepsilon_{t}$ is an error term.

In this paper, we use annual data from 1990 to 2015 for the renewable energy consumption, oil price, income, and $\mathrm{CO}_{2}$ emissions. Our dependent variable is renewable energy consumption (REC). It is expressed by renewable energy consumption as a percentage of total final energy consumption. The oil price (OP) is expressed by US dollars per barrel, which is our main independent variable. The income (GDP) is expressed by real GDP per capita (2010 US dollars). $\mathrm{CO}_{2}$ emissions per capita is expressed in kilotons (kt) of carbon dioxide. The REC, GDP, and $\mathrm{CO}_{2}$ emissions data are compiled from the World Bank database [55]. The data for OP was provided from the Federal Reserve Bank of St. Louis [56]. For empirical analyses, we converted all variables to logarithmic form.

\subsection{Methodology}

In the current article, the effect of oil price, GDP per capita, and $\mathrm{CO}_{2}$ emissions on renewable energy consumption was estimated utilizing the VECM method. In an initial step, the Augmented Dickey Fuller unit root (ADF) [57], Philips-Perron (PP) [58], and Kwiatkowski, Phillips, Schmidt, and Shin (KPSS) [59] tests were applied for determining non-stationarity features of used variables.

In the next step, if the variables' orders of integration are the same, the cointegration test will be employed to determine if they are cointegrated. Therefore, the Johansen test $[60,61]$ was applied to test the cointegration relationship.

Eventually, after verifying the presence of cointegration link between the variables, we examined the long-term relationship between the variables utilizing the Vector Error Correction Model (VECM). In addition, we employed the Canonical Cointegrating Regression (CCR) test in order to obtain more robust results.

We do not explain the methods described above since they are commonly used in many studies. The detailed information can be obtained in the studies by Dickey and Fuller [57], Philips and Perron [58], Kwiatkowski, Phillips, Schmidt, and Shin (KPSS) [59], Johansen [60], Johansen and Juselius [61], and Park [62].

\section{Empirical Results and Discussion}

Employing the ADF, PP, and KPSS unit root tests, the stationarity properties of the variables were first checked. Table 2 summarizes the results of the ADF, PP, and KPSS. As shown by the unit root tests, all of the variables are non-stationary at their level, but they are stationary at first difference. As a result, we can employ the cointegration test.

Table 2. Unit root tests' results.

\begin{tabular}{ccccccccc}
\hline \multirow{2}{*}{ Variable } & \multicolumn{3}{c}{ The ADF Test } & \multicolumn{2}{c}{ The PP Test } & \multicolumn{2}{c}{ The KPSS Test } \\
\cline { 2 - 10 } & Level & $\mathbf{k}$ & \multicolumn{2}{c}{ First Difference k } & Level & First Difference & Level & First Difference \\
\hline$R E C$ & -2.4206 & 0 & $-7.7681^{* * *}$ & 0 & -2.4206 & $-12.710^{* * *}$ & 0.7530 & $0.0649^{* * *}$ \\
$O P$ & -1.2838 & 0 & $-3.6249^{* *}$ & 0 & -1.2358 & $-3.6253^{* *}$ & 0.7814 & $0.1435^{* * *}$ \\
$G D P$ & -0.9593 & 2 & $-3.5340^{* *}$ & 1 & 0.6576 & $-3.5223^{* *}$ & 0.8829 & $0.3339^{* * *}$ \\
$C_{2}^{* * *}$ & 1.4275 & 0 & $-3.9772^{* *}$ & 0 & -1.4375 & $-4.0353^{* * *}$ & 0.7490 & $0.3994^{* *}$ \\
\hline
\end{tabular}

Notes: ADF, PP, and KPSS accordingly refer to the Augmented Dickey-Fuller, Phillips-Perron, and Kwiatkowski, Phillips, Schmidt, Shin tests. Two is determined as maximum lag order and optimal lag order $(\mathrm{k})$ is selected according to Akaike criterion in the ADF test; ${ }^{* *}$, and ${ }^{* * *}$ accordingly refer to rejection of the null hypothesis at $10 \%, 5 \%$, and $1 \%$ significance levels. The critical values are compiled from MacKinnon [63] and Kwiatkowski, Phillips, Schmidt, and Shin [59]. 
In order to use the Johansen cointegration technique, the optimum lag number must first be determined. A Vector Auto Regressive (VAR) model with REC, OP, GDP, and $\mathrm{CO}_{2}$ was initially defined with an arbitrarily designated lag interval, and a determination test of lag interval was employed to the residuals in order to define the optimal lag interval in the sample. The outcomes of this test are depicted in Table 3. All lag selection criteria revealed that a lag of order two is optimal in this study.

Table 3. Lag interval tests.

\begin{tabular}{cccccccc}
\hline & \multicolumn{9}{c}{ Information Criteria } \\
\hline Lag & LogL & LR & FPE & AIC & SC & HQ \\
\hline 0 & 73.27637 & NA & $4.03 \times 10^{-8}$ & -5.676206 & -5.281251 & -5.576876 \\
1 & 144.5878 & 105.4169 & $3.45 \times 10^{-10}$ & -10.48590 & -9.301035 & -10.18791 \\
2 & 174.1625 & $33.43225^{*}$ & $1.29 \times 10^{-10 *}$ & $-11.66631^{*}$ & $-9.691533^{*}$ & $-11.16966^{*}$ \\
3 & 188.9660 & 11.58532 & $2.45 \times 10^{-10}$ & -11.56226 & -8.797577 & -10.86695 \\
\hline
\end{tabular}

${ }^{*}$ Indicates lag order selected by the criterion.

The VAR has worthy characteristics, according to Panels A through D in Table 4, since it becomes stable, the residuals do not show a serial correlation or heteroscedasticity problem, and they have normal distribution.

Table 4. The residual diagnostics of VAR and cointegration tests' results.

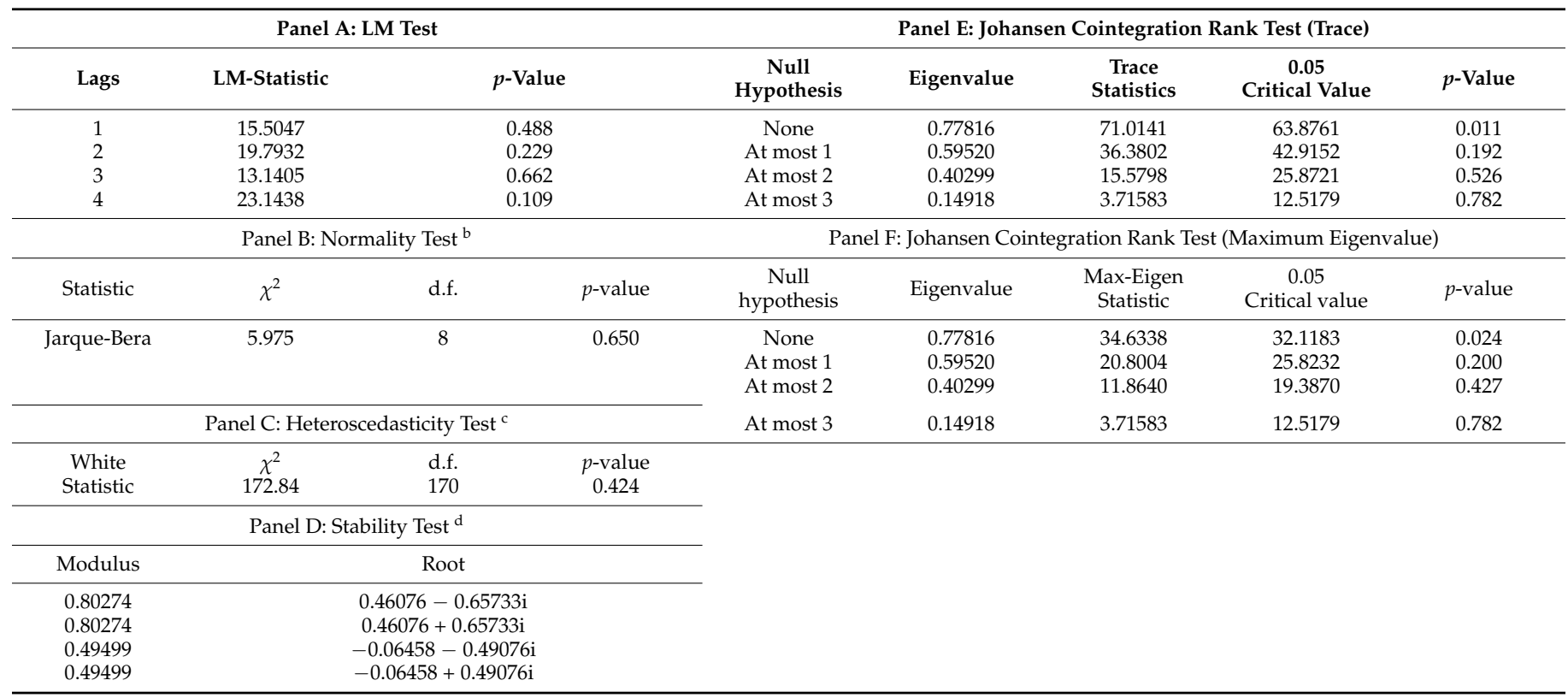

Notes: ${ }^{\text {a }}$ The null hypothesis of the LM Test shows no serial correlation in residuals at second order lag. ${ }^{\mathrm{b}}$ The Normality Test denotes the normal distribution of residuals. ${ }^{\mathrm{c}}$ The null hypothesis of White Heteroscedasticity Test asserts that the residuals have heteroscedasticity problems. ${ }^{d}$ The results of the VAR stability test show that all of the characteristic polynomial's roots are contained within the unit circle. $\chi^{2}$ denotes the Chi-square distribution. d.f. is degrees of freedom.

The cointegration relationship was tested using the Johansen cointegration test. Panels $\mathrm{E}$ and $\mathrm{F}$ of Table 4 present the results of the Johansen cointegration test. The trace and max-eigenvalue test statistics show that the variables have a cointegration relationship. As a result, we conclude that the variables have a cointegrating relationship.

Lastly, we applied the VECM and CCR methods to evaluate coefficients of the long-run relationship among the variables after verifying the existence of cointegration among the variables. The first-best solution would be to employ the VECM method if there is one cointegration relationship between the variables. Additionally, the VECM residuals were also applied to diagnostic tests. The outcomes of VECM and CCR are depicted in Table 5. 
Table 5. Long-run coefficients from the VECM method.

\begin{tabular}{|c|c|c|c|}
\hline \multirow{2}{*}{ Methods } & OP & GDP & $\mathrm{CO}_{2}$ \\
\hline & Coef. (t-Stat.) & Coef. (t-Stat.) & Coef. (t-Stat.) \\
\hline VECM & $-0.43(-2.87) * *$ & $0.99(2.77) * *$ & $-0.66(-1.54)$ \\
\hline CCR & $-0.14(-5.83)^{* * *}$ & $0.20(3.59)^{* * *}$ & $-0.01(-0.44)$ \\
\hline \multicolumn{4}{|c|}{ Residuals diagnostics tests results of VECM } \\
\hline$L M_{S C}$ & & $5.73(0.991)$ & \\
\hline$\chi_{\text {HETR }}^{2}$ & & $104.7(0.14)$ & \\
\hline$J B_{N}$ & & $192.7(0.431)$ & \\
\hline
\end{tabular}

As shown in Table 5, VECM residuals have no serial correlation, instability, or heteroscedasticity problems. As a result, the residuals of the evaluated specifications meet the requirements of residuals diagnostics tests, indicating the estimation results' robustness.

As shown in Table 5, the long-run coefficients of two methods are statistically significant and very similar to each other in terms of both significance and sign. As mentioned in the Methodology Section, the results of the VECM model, which are presented in the first row of Table 5, are given precedence. The VECM results reveal that OP has a statistically significant and negative influence on REC. The results indicate that a $1 \%$ OP per capita leads to a decline in REC by $0.43 \%$. This implies that a rise in oil prices reduces renewable energy consumption. Our outcomes are in line with outcomes of Sadorsky [34] in the case of G7 countries, Salim and Rafiq [35] in the case of China and Indonesia, Omri and Nguyen [36] in the case of 64 countries, Deniz [37] in the case of oil-exporting countries, and Mukhtarov et al. [38] in the case of Azerbaijan. Additionally, we found that there is a positive and statistically significant effect of GDP on REC. This indicates that a $1 \%$ increase in real GDP per capita results in a $0.99 \%$ rise in REC. As shown by the positive impact of income on REC, Russia uses its rising revenues to transition to renewable energy sources. Our findings are consistent with the traditional expectation. In addition, $\mathrm{CO}_{2}$ emissions have a negative and statistically insignificant impact on REC, according to the results.

\section{Conclusions}

The current article investigated the effects of oil price, income, and $\mathrm{CO}_{2}$ on renewable energy consumption. The ADF, PP and KPSS unit root tests revealed that all of the chosen economic indicators have the same integration order, being one. As a result, the existence of a cointegration nexus among the variables was tested. The Johansen cointegration test showed the presence of long-run co-movement. The VECM and CCR methods were applied in the evaluation of a long-run relationship.

For the studied period, empirical findings revealed that income has a positive effect on REC, whereas the oil price has a negative influence on REC in Russia. The adverse effect of oil price on REC implies that Russia goes on to be plagued by high oil prices, which is decelerating the shifting process from conventional to renewable energy sources. In addition, the findings show that $\mathrm{CO}_{2}$ emissions have a negative and statistically insignificant impact on renewable energy consumption. The negative insignificant effect of $\mathrm{CO}_{2}$ emissions on renewable energy use also approves the country's relative disinclination to use alternative energy, as increasing $\mathrm{CO}_{2}$ emissions does not drive the country to formulate a more environmentally friendly policy. According to our results, we can say that the policymakers in Russia and similar oil-exporting countries should increase the portion of renewable energy in the total energy use portfolio for diversifying the economy and achieving sustainable economic development targets. It worth to note that given the limited supply of oil and reducing the impact of fossil fuels on environmental degradation, the production and use of renewable energy should be prioritized. 
Russia has great potential in terms of renewable energy sources as well as fossil fuels. Almost one third of its national income is from export revenues related to fossil fuels. However, both the depletion of fossil fuels and the decline in demand around the world indicate that Russia will lose this advantage in the future. From this point of view, Russia should implement projects that will allow it to use renewable energy sources as soon as possible. In this context, it is of great importance to carry out comprehensive and efficient studies in areas such as solar, wind, geothermal, and biomass.

An important factor in preventing the expansion of Russia's renewable energy production is the unfavorable climate and landforms. Therefore, efficient renewable energy production with traditional equipment cannot be achieved. Therefore, appropriate technological infrastructure investments should be given priority. It will also encourage the expansion of renewable energy facilities, and the implementation of incentive policies such as tax relief, land allocation, low interest, and long-term credit facilities will be of great benefit.

It is possible to list the benefits of the obtained results in a global context as follows: Harmful gases generated by the use of fossil fuels have brought about the problem of global warming and related climate change. The most important step to be taken to combat climate change is to reduce the use of fossil fuels. In this context, a country with a significant share on a global scale, such as Russia, would be of great benefit in the fight against climate change if it gave up fossil fuel production and turned to renewable resources. At the same time, if Russia, which has a great potential in terms of renewable energy sources, will take a step in this regard, just as in fossil fuel production, it will have a global share in renewable energy production. This will serve as a model for other oil-exporting countries.

Author Contributions: All authors contributed equally to all aspects of the research reported in this article. All authors have read and agreed to the published version of the manuscript.

Funding: This research received no external funding.

Institutional Review Board Statement: Not applicable.

Informed Consent Statement: Not applicable.

Conflicts of Interest: The authors declare no conflict of interest.

Nomenclatures:

$\begin{array}{ll}\text { ADF } & \text { Augmented Dickey-Fuller } \\ \text { ARDL } & \text { Autoregressive Distributed Lags Bounds Testing } \\ \text { BRICS } & \text { Brazil, Russia, India, China, South Africa } \\ \mathrm{CO}_{2} & \text { Carbon Dioxide } \\ \text { CPI } & \text { Consumer Price Index } \\ \text { DOLS } & \text { Dynamic Ordinary Least Squares Technique } \\ \text { EU } & \text { European Union } \\ \text { FMOLS } & \text { Fully Modified Ordinary Least Squares Technique } \\ \text { GCC } & \text { Gulf Cooperation Council } \\ \text { GDP } & \text { Gross Domestic Product per capita } \\ \text { GMM } & \text { Generalized Method of Moments } \\ \text { GLS } & \text { Generalized Least Squares } \\ \text { REC } & \text { Renewable Energy Consumption } \\ \text { OP } & \text { Oil Price } \\ \text { OPEC } & \text { The Organization of the Petroleum-Exporting Countries } \\ \text { OECD } & \text { The Organization for Economic Co-operation and Development } \\ \text { OLS } & \text { Ordinary Least Squares } \\ \text { STSM } & \text { The Structural Time Series Modeling } \\ \text { TVC } & \text { Time-Varying Coefficient Cointegration Approach } \\ \text { VECM } & \text { Vector Error Correction Method } \\ \text { VAR } & \text { Vector Autoregression }\end{array}$




\section{References}

1. Jaramillo, P.; Muller, N.Z. Air pollution emissions and damages from energy production in the U.S.: 2002-2011. Energy Policy 2016, 90, 202-211. [CrossRef]

2. Casey, J.A.; Karasek, D.; Ogburn, E.L.; Goin, D.E.; Dang, K.; Braveman, P.A.; Rachel, M.F. Retirements of coal and oil power plants in California: Association with reduced preterm birth among populations nearby. Am. J. Epidemiol. 2018, 187, 1586-1594. [CrossRef] [PubMed]

3. Chikkatur, A.P.; Chaudhary, A.; Ambuj, D.S. Coal power impacts, technology, and policy: Connecting the dots. Annu. Rev. Environ. Resour. 2011, 36, 101-138. [CrossRef]

4. Pope, C.A.; Dockery, D.W. Health effects of fine particulate air pollution: Lines that connect. J. Air Waste Manag. Assoc. 2006, 56, 709-742. [CrossRef] [PubMed]

5. Abel, G.; Jennifer, R.M.; Matthew, H.G.; Xinran, W.; Matthew, T.B.; Seth, A.R.; Anthony, L. Blame Where Blame Is Due: Many Americans Support Suing Fossil Fuel Companies for Global Warming Damages. Environ. Sci. Policy Sustain. Dev. 2020, 62, 30-35. [CrossRef]

6. Giovanni, N.; Natale, A.; Gerardo, N.; Roberto, B. A technical and environmental comparison between hydrogen and some fossil fuels. Energy Convers. Manag. 2015, 89, 205-213. [CrossRef]

7. Dincer, I.; Marc, A.R. Sustainability aspects of hydrogen and fuel cell systems. Energy Sustain. Dev. 2011, 15, 137-146. [CrossRef]

8. Zhao, H.R.; Guo, S.; Fu, L.W. Review on the costs and benefits of renewable energy power subsidy in China. Renew. Sustain. Energy Rev. 2014, 37, 538-549. [CrossRef]

9. Barbir, F. Transition to renewable energy systems with hydrogen as an energy carrier. Energy 2009, 34, 308-312. [CrossRef]

10. Bilgili, M.; Ozbek, A.; Sahin, B.; Kahraman, A. An overview of renewable electric power capacity and progress in new technologies in the World Renew. Sustain. Energy Rev. 2015, 49, 323-334. [CrossRef]

11. Wüstenhagen, R.; Wolsink, M.; Bürer, M.J. Social acceptance of renewable energy innovation: An introduction to the concept. Energy Policy 2007, 35, 2683-2691. [CrossRef]

12. Troster, V.; Shahbaz, M.; Gazi, U.S. Renewable energy, oil prices, and economic activity: A Granger-causality in quantiles analysis. Energy Econ. 2018, 70, 440-452. [CrossRef]

13. Imad, J. The shift in US oil demand and its impact on OPEC's market share. Energy Econ. 2001, 6, 659-666. [CrossRef]

14. Kilian, L. Not All Oil Price Shocks Are Alike: Disentangling Demand and Supply Shocks in the Crude Oil Market. Am. Econ. Rev. 2009, 99, 1053-1069. [CrossRef]

15. Baffes, J.; Kose, M.A.; Ohnsorge, F.; Stocker, M. The Great Plunge in Oil Prices: Causes, Consequences, and Policy Responses. 2015. Available online: https:/ / ssrn.com/abstract=2624398 (accessed on 18 June 2020). [CrossRef]

16. Hamilton, J.D. Causes and Consequences of the Oil Shock of 2007-08. Natl. Bur. Econ. Res. 2009. [CrossRef]

17. Weijermars, R.; Clint, O.; Pyle, I. Competing and partnering for resources and profits: Strategic shifts of oil Majors during the past quarter of a century. Energy Strategy Rev. 2014, 3, 72-87. [CrossRef]

18. Ferrer, R.; Shahzad, S.J.H.; López, R.; Jareño, F. Time and frequency dynamics of connectedness between renewable energy stocks and crude oil prices. Energy Econ. 2018, 76, 1-20. [CrossRef]

19. Lee, D.; Baek, J. Stock prices of renewable energy firms: Are there asymmetric responses to oil price changes? Economies 2018, 6, 59. [CrossRef]

20. Hsiao, C.Y.L.; Lin, W.; Wei, X.; Yan, G.; Li, S.; Sheng, N. The impact of international oil prices on the stock price fluctuations of China's renewable energy enterprises. Energies 2019, 12, 4630. [CrossRef]

21. Henriques, I.; Sadorsky, P. Oil prices and the stock prices of alternative energy companies. Energy Econ. 2008, 30, 998-1010. [CrossRef]

22. Reboredo, J.C. Is there dependence and systemic risk between oil and renewable energy stock prices? Energy Econ. 2015, 48, 32-45. [CrossRef]

23. Pata, U.K. The influence of coal and noncarbohydrate energy consumption on $\mathrm{CO}_{2}$ emissions: Revisiting the environmental Kuznets curve hypothesis for Turkey. Energy 2018, 160, 1115-1123. [CrossRef]

24. Omri, A.; Daly, S.; Nguyen, D.K. A robust analysis of the relationship between enewable energy consumption and its main drivers. Appl. Econ. 2015, 47, 2913-2923. [CrossRef]

25. Deniz, P. Oil Prices and Renewable Energy: An Analysis for Oil Dependent Countries. J. Res. Econ. 2019, 3, 139-152. [CrossRef]

26. Mukhtarov, S.; Mikayilov, I.J.; Humbatova, S.; Muradov, V. Do High Oil Prices Obstruct the Transition to Renewable Energy Consumption? Sustainability 2020, 12, 4689. [CrossRef]

27. Sadorsky, P. Renewable energy consumption, CO2 emissions and oil prices in the G7 countries. Energy Econ. 2009, 31, 456-462. [CrossRef]

28. Salim, R.A.; Rafiq, S. Why do some emerging economies proactively accelerate the adoption of renewable energy? Energy Econ. 2012, 34, 1051-1057. [CrossRef]

29. Omri, A.; Nguyen, D.K. On the determinants of renewable energy consumption: International evidence. Energy 2014, 72, 554-560. [CrossRef]

30. Murshed, M.; Tanha, M.M. Oil price shocks and renewable energy transition: Empirical evidence from net oil-importing South Asian economies. Energy Ecol. Environ. 2020, 1-21. [CrossRef] 
31. Marques, A.C.; Fuinhas, J.A. Drivers promoting renewable energy: A dynamic panel approach. Renew. Sustain. Energy Rev. 2011, 15, 1601-1608. [CrossRef]

32. Nguyen, K.H.; Kakinaka, M. Renewable energy consumption, carbon emissions, and development stages: Some evidence from panel cointegration analysis. Renew. Energy 2019, 132, 1049-1052. [CrossRef]

33. Energy Information Administration (EİA). Russia. 2021. Available online: https://www.eia.gov/international/rankings/ country / RUS? pa $=12 \& u=0 \& f=A \& v=$ none $\& y=01 \% 2 F 01 \% 2 F 2018$ (accessed on 22 March 2021).

34. Enerdata. Russia Related Research. 2021. Available online: https://www.enerdata.net/estore/energy-market/russia/ (accessed on 12 March 2021).

35. Our World in Data, Russia: How Is Energy Consumption Changing from Year-to-Year? 2021. Available online: https:// ourworldindata.org/energy/country/russia (accessed on 20 March 2021).

36. Fortov, V.E.; Popel, O.S. The current status of the development of renewable energy sources worldwide and in Russia. Therm. Eng. 2014, 61, 389-398. [CrossRef]

37. Matraeva, L.; Solodukha, P.; Erokhin, S.; Babenko, M. Improvement of Russian energy efficiency strategy within the framework of "green economy" concept (based on the analysis of experience of foreign countries). Energy Policy 2019, 125, 478-486. [CrossRef]

38. Gusev, A. Comparison of Energy Efficiency Measures in Russia to Those Implemented by Developed Countries (Including IEA Measures); German Institute for International and Security Affairs (SWP): Berlin, Germany, 2013.

39. IRENA. Remap 2030 Renewable Energy Prospects for the Russian Federation, Working Paper, Abu Dhabi. 2017. Available online: www.irena.org/remap (accessed on 22 March 2021).

40. Cherepovitsyn, A.; Tcvetkov, P. Overview of the prospects for developing a renewable energy in Russia. Int. Conf. Green Energy Appl. ICGEA 2017, 113-117. [CrossRef]

41. Tatiana, A.L.; Laitner, J.A.; Potashnikov, Y.V.; Barinova, V.A. The slow expansion of renewable energy in Russia: Competitiveness and regulation issues. Energy Policy 2018, 120, 600-609. [CrossRef]

42. Mitrova, T.; Melnikov, Y. Energy transition in Russia. Energy Transit. 2019, 3, 73-80. [CrossRef]

43. CMS. The Renewable Energy Law Review (Russia). 2019. Available online: https://cms.law/en/rus/publication/the-renewableenergy-law-review (accessed on 7 May 2021).

44. The International Renewable Energy Agency (IRENA). The Energy Technology Mix in Russia. 2021. Available online: https: //www.irena.org/Statistics/View-Data-by-Topic/Innovation-and-Technology/Patents-Evolution (accessed on 7 May 2021).

45. Apergis, N.; Payne, J.E. The causal dynamics between renewable energy, real GDP, emissions and oil prices: Evidence from OECD countries. Appl. Econ. 2014, 46, 4519-4525. [CrossRef]

46. Apergis, N.; Payne, J.E. Renewable energy, output, $\mathrm{CO}_{2}$ emissions, and fossil fuel prices in Central America: Evidence from a nonlinear panel smooth transition vector error correction model. Energy Econ. 2014, 42, 226-232. [CrossRef]

47. Azad, A.K.; Rasul, M.G.; Khan, M.M.K.; Omri, A.; Bhuiya, M.M.K.; Ali, M.H. Modelling of renewable energy economy in Australia. Energy Procedia 2014, 61, 1902-1906. [CrossRef]

48. Apergis, N.; Payne, J.E. Renewable energy, output, carbon dioxide emissions, and oil prices: Evidence from South America. Energy Sources B Econ. Plan. Policy 2015, 10, 281-287. [CrossRef]

49. Bamati, N.; Roofi, A. Development level and the impact of technological factor on renewable energy production. Renew. Energy 2020, 151, 946-955. [CrossRef]

50. Tuzcu, S.E.; Tuzcu, A. Renewable Energy and Proven Oil Reserves Relation: Evidence from OPEC Members. Çankırı Karatekin Üniversitesi İktisadi ve İdari Bilimler Fakültesi Dergisi 2014, 4, 121-136.

51. Brini, R.; Amara, M.; Jemmali, H. Renewable energy consumption, International trade, oil price and economic growth interlinkages: The case of Tunisia. Renew. Sustain. Energy Rev. 2017, 76, 620-627. [CrossRef]

52. Alege, P.; Jolaade, A.; Adu, O. Is there Cointegration between Renewable Energy and Economic Growth in Selected Sub-saharan African Counries? Int. J. Energy Econ. Policy 2018, 8, 219-226.

53. Payne, J.E. The causal dynamics between US renewable energy consumption, output, emissions, and oil prices. Energy Sources $B$ Econ. Plan. Policy 2012, 7, 323-330. [CrossRef]

54. Ji, Q.; Zhang, D. How much does financial development contribute to renewable energy growth and upgrading of energy structure in China? Energy Policy 2019, 128, 114-124. [CrossRef]

55. World Bank (WB). World Development Indicators. 2021. Available online: https://data.worldbank.org/indicator/ (accessed on 11 February 2021).

56. Federal Reserve Bank of, St. Louis-FRED. Federal Reserve Economic Data. 2021. Available online: https://fred.stlouisfed.org (accessed on 11 February 2021).

57. Dickey, D.; Fuller, W. Likelihood Ratio Statistics for Autoregressive Time Series with a Unit Root. Econometrica 1981, 49, 1057-1072. [CrossRef]

58. Phillips, P.B.; Perron, P. Testing for Unit Roots in Time Series Regression. Biometrika 1988, 75, 335-346. [CrossRef]

59. Kwiatkowski, D.; Phillips, P.C.B.; Schmidt, P.; Shin, Y. Testing the null hypothesis of stationarity against the alternative of a unit root. J. Econom. 1992, 54, 159-178. [CrossRef]

60. Johansen, S. Statistical analysis of cointegration vectors. J. Econ. Dyn. Control 1988, 12, 231-254. [CrossRef] 
61. Johansen, S.; Juselius, K. Maximum likelihood estimation and inference on cointegration with applications to the demand for money. Oxf. Bull. Econ. Stat. 1990, 52, 169-210. [CrossRef]

62. Park, J. Canonical cointegrating regressions. Econometrica 1992, 60, 119-143. [CrossRef]

63. Mackinnon, J.G. Numerical Distribution Functions for Unit Root and Cointegration Test. J. Appl. Econ. 1996, 11, 601-618. [CrossRef] 